\section{Synovial Osteochondromatosis Mimicking Septic Arthritis}

\author{
ABSTRACT \\ Synovial osteochondromatosis is an uncommon benign condition with rare malignant \\ potential. We describe an unusual case of synovial osteochondromatosis in a very \\ elderly lady, who presented with an acute painful swollen knee, mimicking septic \\ arthritis. This required knee replacement for long-term symptom control.
}

\section{KEY WORDS}

Synovial osteochondromatosis, painful swollen knee, knee replacement

\author{
Shweta Gupta, Prantesh \\ Jain \\ Department of Medicine \\ John H Stroger Jr Hospital of Cook \\ County 1900 W Polk St, $15^{\text {th }}$ Floor \\ Chicago, IL 60612 \\ USA

\section{Correspondence}

\section{Shweta Gupta, MD} \\ Div of Hematology-Oncology \\ John H Stroger Jr Hospital of Cook \\ County \\ 1900 W Polk St, $7^{\text {th }}$ Floor \\ Chicago, IL 60612, USA \\ Phone: +1-312-864-7250 \\ Fax: +1-312-864-9002 \\ Email: shwets2@yahoo.com
}

Submitted: September 3, 2011

Accepted: September 20, 2011
Synovial osteochondromatosis is an uncommon benign condition with rare malignant potential, where there is formation of cartilaginous or osteocartilaginous loose bodies within and around the joint space of a joint. It could be asymptomatic or present with joint symptoms similar to osteoarthritis. There are cases described in literature involving large and small joints, with the youngest reported age of seventeen to oldest in the sixties.

We describe an unusual case of synovial osteochondromatosis in a very elderly lady, who presented with an acute painful swollen knee, mimicking septic arthritis and required knee replacement for long-term symptom control.

\section{Case Presentation}

We present a case of a 75 years old lady with a history of osteoarthritis of the knees bilaterally who was admitted to the hospital with complaints of worsening pain in the right knee since one day. She was taking off and on pain medications and was able to walk without support. She woke up in the morning the day of admission and heard a cracking sound from the right knee after which the pain started. Over the course of the day the pain worsened and movements of the right knee joint became more painful, so much so that she was walking with a limp by evening. The knee also got swollen and painful to touch. Her left knee was at baseline with mild pain, no new changes and no swelling or tenderness. She denied any fever or preceding trauma to the joint. She also denied any previous history of similar complaints. She was taking off and on pain medications, namely Tylenol and ibuprofen, and was able to walk without support before this presentation.
Physical exam showed a healthy elderly woman in some distress due to pain. Her vital signs were normal. Systemic exam showed clear lung fields to auscultation, normal heart sounds with no murmurs, normal abdominal exam. She had no apparent focal neurological deficits. Examination of the right knee joint showed that it was swollen and erythematous anteriorly. On palpation the knee was tender and range of motion was restricted due to pain and swelling to $30 \mathrm{de}-$ grees flexion and unable to be fully extended. There was a moderate effusion in the right knee joint as well.

In the emergency room she was given pain medications, an X-ray of the knee was ordered and arthrocentesis of the right knee was performed to rule out a septic joint. Her complete blood count was normal with no increase in white cells and no left shift. The electrolytes, renal function and liver function tests were normal as well. The imaging showed popcorn calcifications in and around the right knee joint as shown in Figure 1-3. There was no fracture. The synovial fluid analysis showed 90,000 red blood cells with total white cell count of 550 cells with $10 \%$ polymorphs, 10\% lymphocytes and 80\% monocytes. There were no crystals seen and the gram stain was negative with final cultures reported negative as well.

The above was consistent with a diagnosis of synovial osteochondromatosis, which likely caused one of the calcifications to break loose in the joint space, causing locking and a cracking sound with internal trauma and some bleeding as seen in the synovial fluid analysis. She was managed conservatively with pain medications and hot fomentation and her knee improved. The orthopedic service 

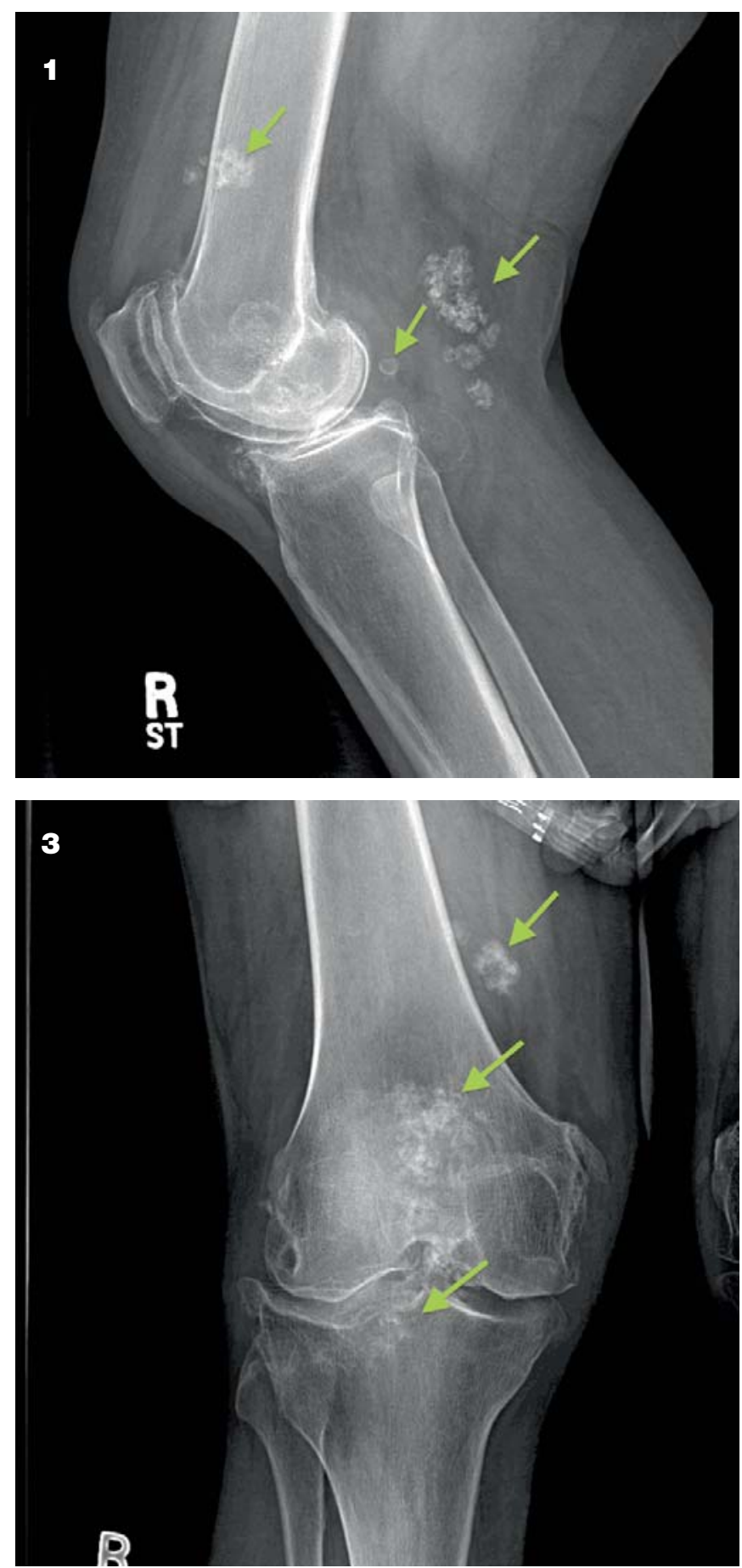

Fig 1, 2 and 3. Popcorn calcifications in and around right knee joint AP and lat views

was consulted for opinion and they agreed with conservative management at the time. She was discharged in stable condition with follow-ups with medicine and orthopedics. However her symptoms persisted intermittently and interfered with daily activities. Hence two months later, due to presence of long standing baseline osteoarthritis and added osteochondromatosis, it was decided to offer her total

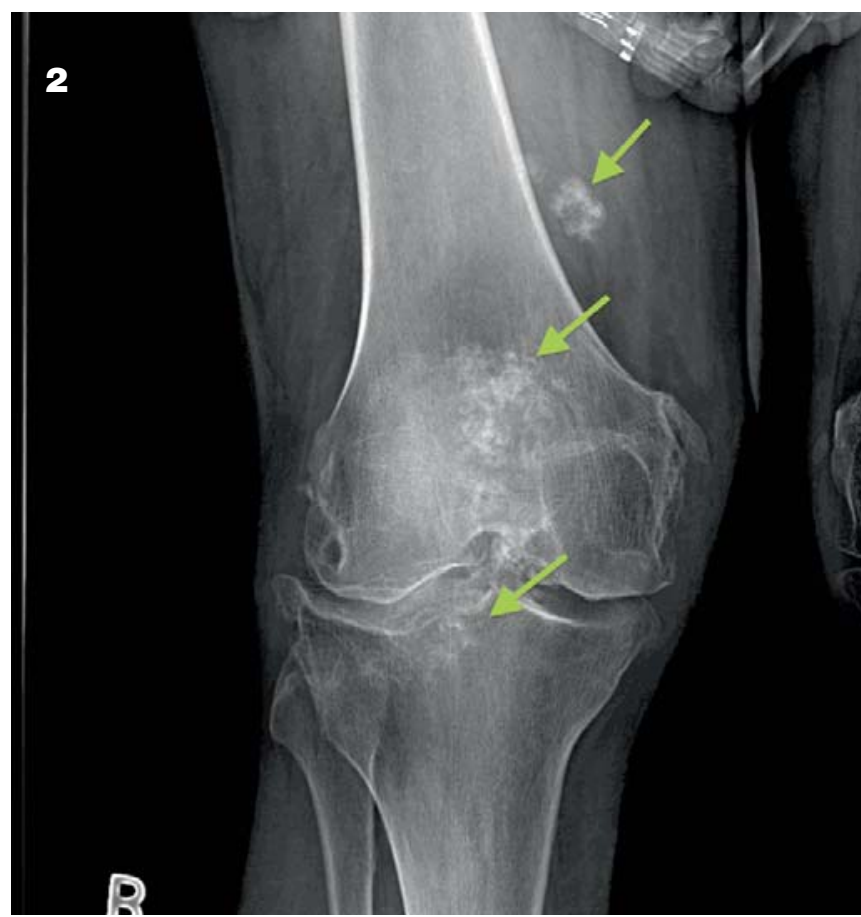

knee replacement and she agreed. Post surgery imaging is shown in Figure 4. At this time with more than 30 months after replacement, she continues to do well and is being followed in the general medicine clinic.

\section{Discussion}

Synovial osteochondromatosis is an entity, which has been described in literature as early as the early 2oth century ${ }^{1}$. Dr Mussey, in 1949 described osteochondromatosis as a condition in which cartilaginous and osteocartilaginous bodies are formed within and by the synovial membranes of joints and, occasionally, of bursae and tendon sheaths ${ }^{1}$. It was shown in 1927 that microscopically formation of these bodies follow the same stages that occur in the embryonic formation of the cartilage ${ }^{3}$.

Since then, there have been case reports of osteochondromatosis with two case series. In 1977 Milgram proposed a classification of the disease entity into 3 phases: (1) active intra synovial disease only, with no loose body; (2) transitional lesions, with both active intra synovial proliferation and free loose bodies; and (3) multiple free osteochondral bodies with no demonstrable intra synovial disease ${ }^{4}$.

Synovial chondromatosis is characteristically a monoarticular condition, which has been described to affect large joints most commonly knee and elbow ${ }^{1,5}$, however over the past decade there have been reports of involvement of temporo-mandibular joint, lumbar spine ${ }^{6,7}$, hip, and finger $^{2}$. The age at presentation has been described as low as 17 years to as high as $64^{2,6,7}$. The disease has a predilection for men; however, the TMJ cases are more common in women 6 . 


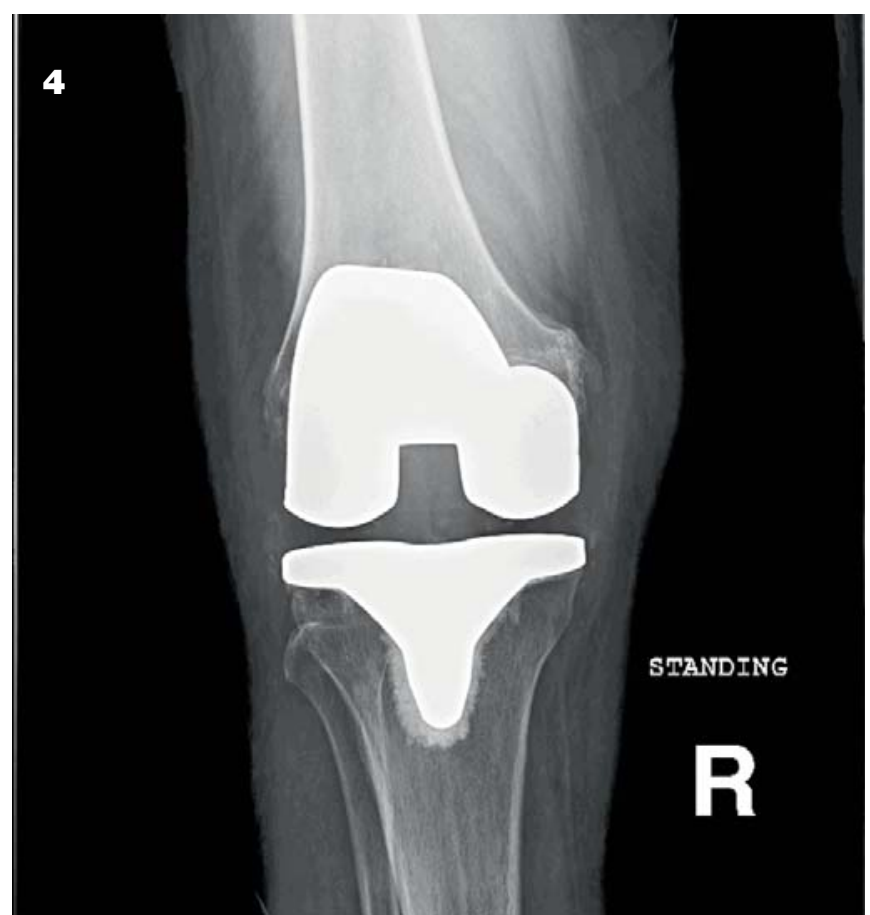

Fig 4. Right knee post replacement

Clinical presentation could be non-specific, with most commonly reported symptoms being pain, stiffness, swelling and history of limitation of movement of the affected joint with occasional reports of locking of the joint ${ }^{8}$. Symptoms may occur with no history of preceding trauma. Exam can reveal joint tenderness with decreased range of motion. Imaging may show multiple radio opaque loose bodies in many but not all cases (depending on the phase of disease) $)^{8}$.

Treatment traditionally includes removal of loose bodies with or without synovectomy. It is generally regarded as a benign condition with rare progression to chondrosarcoma, with one case series of 53 cases showing malignant transformation in $5 \%$ of cases ${ }^{2}$. Recurrence rates despite treatment of up to $15 \%$ have been described ${ }^{2}$.

Our case is unique where synovial osteochondromatosis occurred in a very elderly 75 years old lady with majority of the calcification being outside the joint spaces in the soft tissues. Also, the joint space loose bodies caused acute atraumatic locking with hemorrhagic joint effusion within the joint space, and the constellation of knee findings seemed clinically like a septic joint. The symptoms were severe enough to warrant a total knee replacement, a measure not reported for this disease, after which there was complete resolution of symptoms.

No potential conflict of interest relevant to this article was reported.

\section{References}

1. Robert D Mussey Jr, Melvin S. osteochondromatosis. J Bone Joint Surg Am 1949; 31:619-27.

2. Davis RI, Hamilton A, Biggart JD. Primary Synovial Chondromatosis: A Clinicopathologic Review and Assessment of Malignant Potential. Human Pathology 1998;29:683-8.

3. Jones HT. Loose body formation in synovial osteochondromatosis with special references to the etiology and pathology. J Bone Joint Surg 1927;6:407-58.

4. Milgram JW. Synovial osteochondromatosis: a histopathological study of thirty cases. J Bone Joint Surg Am 1977;59:792-801.

5. Crotty JM, Monu JU, Pope TL Jr. Synovial osteochondromatosis. Radiol Clin North Am 1996;34:327-34.

6. Boffano P, Viterbo S, Bosco GF. Diagnosis and surgical management of synovial chondromatosis of the temporo-mandibular joint. J Craniofac Surg 2010;21:157-9.

7. Kim SW, Choi JH. Synovial chondromatosis presenting with lumbar radiculopathy. Spine 2009;34:E414-7.

8. Iyengar J, Luke A, Ma CB. An unusual presentation of synovial chondromatosis of the knee: A case report. Clin J Sport Med 2007;17:157-9.

\section{Sinovijalna osreohondromatoza koja liči na septički artritis}

\section{Shweta Gupta, Prantesh Jain}

\section{APSTRAKT}

Sinovijalna osteohondromatoza je retko benigno oboljenje koje ima mali maligni potencijal. Mi opisujemo neobičan slučaj sinovijalne osteohondromatoze kod starije žene (75 godina) koja nam se javila s akutnim bolom i otečenim kolenom, stanjem koje je ličilo na septički artritis. Simptomi su bili tako teški da je bilo neophodno ugraditi veštačko koleno kako bi se postiglo dugotrajno otklananje tih simptoma.

\section{KLJUČNE RIJEČI}

Sinovijalna osteohondromatoza, bolni otok kolena, veštačko koleno 